\title{
EXPLAINING TRANSPHOBIA AND DISCRIMINATION AGAINST TRANS PEOPLE: A REVIEW OF THEORETICAL APPROACHES
}

\author{
EXPLICAR A TRANSFOBIA E A DISCRIMINAÇÃO CONTRA AS \\ PESSOAS TRANS: UMA REVISÃO DE PERSPECTIVAS TEÓRICAS \\ EXPLICANDO LA TRANSFOBIA $\Upsilon$ LA DISCRIMINACIÓN CONTRA LAS \\ PERSONAS TRANS: UNA REVISIÓN DE ENFOQUES TEÓRICOS
}

\author{
Sara Aguirre-Sánchez-Beato ${ }^{1}$
}

${ }^{1}$ Université libre de Bruxelles, Bruxelles, Belgium

\begin{abstract}
Transphobia and discrimination against trans people are widespread. In view of growing scientific interest in understanding this type of discrimination and considering that scientific knowledge shapes the way a phenomenon is understood and addressed, this paper aims at identifying theoretical perspectives and categories used in contemporary scientific research (2005-2016) to explain discrimination against trans people. A review of literature and a qualitative content analysis of the selected documents $(\mathrm{N}=68)$ were carried out. Two broad theoretical perspectives were identified: cognitive approaches and discursive approaches. The limitations of the two approaches are discussed in terms of how the problem of transphobia and discrimination is framed and explained and the scope for action offered. To overcome such limitations, a conceptual distinction between gendered practices and transphobic attitudes and ideology is suggested and an alternative theoretical proposal using discursive psychology is presented.

KEYWORDS: Transgender; Transsexual; Discrimination; Transphobia.
\end{abstract}

RESUMO: A transfobia e a discriminação contra as pessoas trans apresentam níveis alarmantes. Diante do crescente interesse científico em compreender este tipo de discriminação e considerando que o conhecimento científico influi na forma como um fenômeno é entendido e estudado, objetiva-se identificar as perspectivas teóricas e as categorias utilizadas na literatura científica contemporânea (2005-2016) para explicar a discriminação contra as pessoas trans. Realizou-se revisão da literatura e análise de conteúdo qualitativa de documentos $(\mathrm{N}=68)$. Identificou-se duas perspectivas teóricas: cognitivas e discursivas. Apresenta-se as limitações de ambas as abordagens em relação à conceitualização e à explicação do problema, além das possibilidades de ações que oferecem. Diante destas limitações, argumenta-se favoravelmente a uma distinção conceitual entre práticas generificadas e atitudes e ideologia transfóbica, apresentando uma proposta teórica alternativa a partir da psicologia discursiva.

PALAVRAS-CHAVE: Transgeneridades; Transexual; Discriminação; Transfobia.

RESUMEN: La transfobia y la discriminación contra las personas trans están muy extendidas. Ante el creciente interés científico por comprender este tipo de discriminación y considerando que el conocimiento científico configura la forma en que se comprende y aborda un fenómeno, este artículo tiene como objetivo identificar las perspectivas teóricas y las categorías utilizadas en la investigación científica contemporánea (2005-2016) para explicar la discriminación contra las personas trans. Se realizó una revisión de la literatura y un análisis de contenido cualitativo de los documentos seleccionados $(\mathrm{N}=68)$. Se identificaron dos amplias perspectivas teóricas: enfoques cognitivos y enfoques discursivos. Se discuten las limitaciones de los dos enfoques en términos de cómo se enmarca y explica el problema de la transfobia y la discriminación y el campo de acción ofrecido. Para superar tales limitaciones, se sugiere una distinción conceptual entre prácticas de género y actitudes e ideología transfóbicas y se presenta una propuesta teórica alternativa utilizando la psicología discursiva.

PALABRAS CLAVE: Transgénero; Transexual; Discriminación; Transfobia. 


\section{Introduction}

Trans people are increasingly visible. A number of celebrities have recently 'come out' as trans and National Geographic put a transgender girl on the cover of its 2016 special issue on the 'gender revolution'. According to Platero (2015), representations of trans people in the public and cultural scene appear to be more positive than in previous decades. However, trans people still face pervasive transphobia ${ }^{1}$, violence and discrimination all over the world (Amnesty International, 2014; European Union Agency for Fundamental Rights, 2014; Transgender Europe, 2016). Despite the increased number of publications on trans experiences, most studies focus on documenting discrimination against trans people and not so many explain how and why it occurs (Riggs, 2014).

Different theories and approaches may explain the problem of discrimination against trans people in different ways and the adoption of a specific perspective is not irrelevant. On the one hand, knowledge produced by research contributes to establishing the criteria through which a phenomenon is understood and analysed (Doménech \& Íñiguez-Rueda, 2002). On the other hand, different approaches not only provide specific understandings of discrimination, but also frame the strategies to address it (Reisigl \& Wodak, 2001). Identifying the theoretical perspectives used in research is therefore important to address the implications in terms of how the problem of discrimination is framed and explained and the scope for action offered.

Considering the greater public focus on trans people, we can expect growing scientific interest in explaining discrimination against them. In view of the above and to contribute to future research on the topic, the objective of this paper is to identify the theoretical perspectives and explanatory categories used in contemporary scientific research (20052016) to explain discrimination against trans people and to discuss the implications.

To achieve this objective, a review of the literature and a qualitative content analysis were carried out. In the next section I describe the method and procedure. The section 'Results: Theoretical perspectives and explanatory elements' presents the two perspectives identified in the analysis: cognitive approaches and discursive approaches. In the Discussion section, I address the implications of these two perspectives. Following the step, I present a discursive psychology theoretical proposal and the conclusions.

\section{Method and procedure}

The literature review was carried out through a systematic search of the following databases: Redalyc, Cairn, Scopus, JSTOR and DOAJ. Redalyc and Cairn are regional databases that include articles in Portuguese and Spanish, and French respectively. Scopus and JSTOR are relevant international databases and DOAJ includes open access journals that may not be incorporated in the other four.

Whereas prejudices, stereotypes and discrimination are traditional research topics in social psychology, I decided not to limit the review to the discipline of psychology to broaden the scope of theoretical perspectives. I therefore looked for articles, book chapters and books published from January 2005 to September 2016 in the field of social and human sciences. 
The keywords ${ }^{2}$ and Boolean operators used to identify the documents were: (a) 'ex clusion'/'discrimination'/'stereotypes or prejudices' combined with 'transgender or transsexual or travesti', and (b) the term 'transphobia' entered in English, Portuguese, Spanish and French into the five databases. The keywords were searched for in the abstract when this option was available (Scopus, CAIRN) or in the full text when it was not (JSTOR, DOAJ, Redalyc). The number of documents found per database (all languages) is shown in Table 1.

Table 1. Total number of documents found per database and combination of keywords

\begin{tabular}{lllllll} 
Keyword(s) 1 & Keyword(s) 2 & Scopus & JSTOR & DOAJ & Redalyc & CAIRN \\
\hline Transgender OR & Discrimination & 424 & 612 & 49 & 504 & 21 \\
transsexual & Prejudice OR stereotype & 130 & 511 & 7 & 688 & 0 \\
(OR travesti) & Exclusion & 77 & 176 & 19 & 440 & 0 \\
Transphobia & - & 136 & 41 & 19 & 153 & 4
\end{tabular}

After eliminating all duplicate documents $(\mathrm{N}=413)$, I read the title, abstract and introduction of documents, using the following criteria for their final inclusion in the review:

- Documents written in English, Portuguese, Spanish or French.

- As the main objective is to explain transphobia/exclusion/discrimination against trans people, I excluded: (a) documents dealing exclusively with documenting this type of discrimination (percentages of trans people reporting discrimination) and/or with its consequences (health impacts, psychological distress) and (b) documents in which trans people are only mentioned under the LGBT acronym or sexual minority umbrella but not really targeted.

After an initial reading of the whole body of the documents, other texts that were mentioned but not identified in the initial search were added because of their relevance to the topic, including grey literature. The final corpus covered 68 documents (62 articles, 3 book chapters, 2 books and 1 research report).

The methodology used for analysing the corpus was qualitative content analysis (Andréu Abela, 2000). Content analysis is a text interpretation technique that can be applied to any type of data record and uses codes as the systematic fundamental element to describe the characteristics of the data content. It aims at systematising and explaining the content of texts with the help of hints, quantifiable or not.

I employed an inductive approach to identify theoretical perspectives and explanatory categories and subcategories. Using software for qualitative data analysis (ATLAS.ti 7 for Windows), I attributed codes to units of meaning in a process of coding and recoding following a reiterative process. Two broad theoretical perspectives - cognitive approaches and discursive approaches - and three explanatory categories within each perspective were identified. Results are briefly presented in Figure 1 and described in detail in the next section. 
Figure 1. Theoretical perspectives and explanatory categories
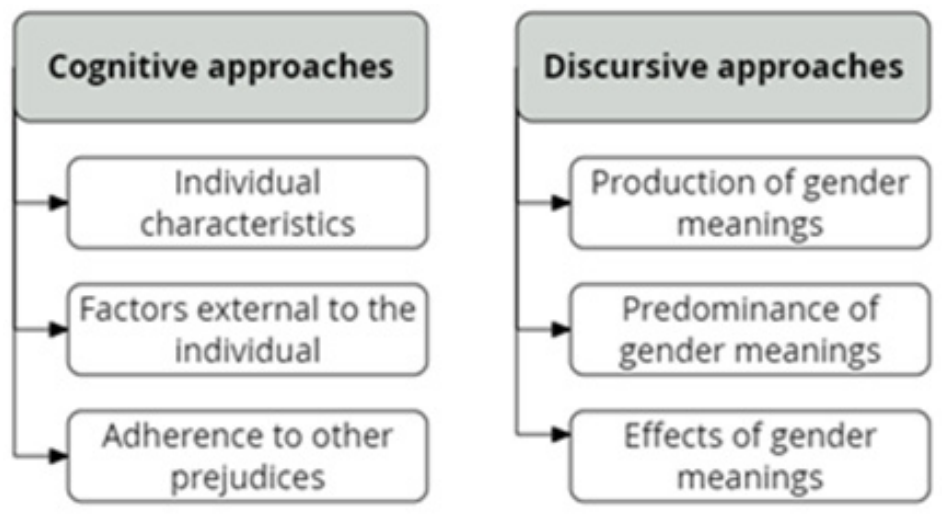

\section{Results: Theoretical perspectives and explanatory categories}

\section{Cognitive approaches}

Under cognitive approaches I included studies that draw on a clear-cut distinction between cognition and behaviour. In these approaches, discriminatory behaviours are explained by prejudiced beliefs and attitudes. Almost all studies come from the discipline of psychology.

Two main concepts are used to explain discriminatory behaviours against trans people: transphobia and trans prejudice (also called anti-trans prejudice and prejudice against trans people). 'Transphobia' was initially defined by Hill \& Willoughby (2005, p. 533) as 'emotional disgust toward individuals who do not conform to society's gender expectations'. However, mirroring debates over the concept of homophobia, the notion of transphobia has been criticised because of its connections with irrational fear, potentially leading to the idea that it is an illness. Therefore, the term 'trans prejudice' was proposed as a way of moving away from the idea of fear or illness towards the individual internalisation of beliefs about trans people. Such beliefs, termed 'trans stigma', are a 'shared belief system through which transgenderism and transsexuality are delegitimized and constructed as invalid relative to heteronormativity' (King et al., 2009, p. 19).

The aim of these studies is to identify the causes leading individuals to adhere to or internalise stereotypes and prejudices against trans people. The methodology used to identify leading causes is quantitative (questionnaires and experiments). Three categories explaining adherence or internalisation of trans stigma were identified: individual characteristics, factors external to the individual and adherence to other types of prejudices (Table 2 ). 
Table 2. Categories and subcategories explaining transphobia and trans prejudice

\begin{tabular}{|c|c|c|}
\hline \multicolumn{2}{|c|}{ Category and subcategory } & References \\
\hline \multirow{12}{*}{ 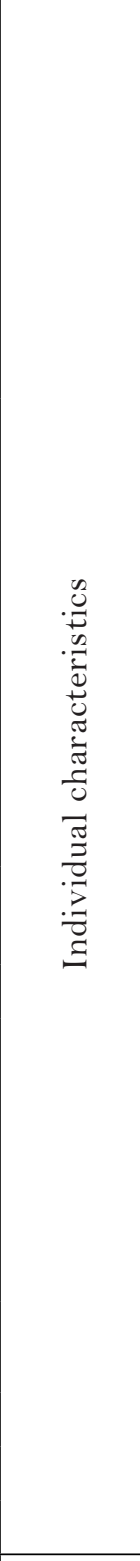 } & Gender & $\begin{array}{l}\text { Ali, Fleisher, \& Erickson, 2016; Case \& Stewart, 2013; } \\
\text { Dierckx, Motmans, \& Meier, 2014; Gazzola \& Morrison, 2014; } \\
\text { Gerhardstein \& Anderson, 2010; Grigoropoulos \& Kordoutis, } \\
\text { 2015; Hill \& Willoughby, 2005; Huffaker \& Kwon, 2016; King, } \\
\text { Winter, \& Webster, 2009; Nagoshi et al., 2008; Norton \& } \\
\text { Herek, 2013; Páez, Hevia, Pesci, \& Rabbia, 2015; E. N. Tebbe } \\
\text { \& Moradi, 2012; Tee \& Hegarty, 2006; Walch, Ngamake, } \\
\text { Francisco, Stitt, \& Shingler, 2012; Warriner, Nagoshi, \& } \\
\text { Nagoshi, 2013; Willoughby et al., 2010; Worthen, 2016 }\end{array}$ \\
\hline & Sexual orientation & $\begin{array}{l}\text { Ali et al., 2016; Case \& Stewart, 2013; Dierckx et al., 2014; } \\
\text { Páez et al., 2015; Tee \& Hegarty, 2006; Warriner et al., 2013; } \\
\text { Willoughby et al., 2010; Worthen, } 2016\end{array}$ \\
\hline & $\begin{array}{l}\text { Religiosity/religious } \\
\text { fundamentalism }\end{array}$ & $\begin{array}{c}\text { Ali et al., 2016; Dierckx et al., 2014; Grigoropoulos \& } \\
\text { Kordoutis, 2015; Huffaker \& Kwon, 2016; King et al., 2009; } \\
\text { Nagoshi et al., 2008; Páez et al., 2015; Tee \& Hegarty, 2006; } \\
\text { Warriner et al., 2013; } \\
\text { Willoughby et al., 2010 }\end{array}$ \\
\hline & Age & $\begin{array}{c}\text { Case \& Stewart, 2013; Dierckx et al., 2014; } \\
\text { King et al., } 2009\end{array}$ \\
\hline & Educational level & $\begin{array}{l}\text { Dierckx et al., 2014; Huffaker \& Kwon, 2016; King et al., 2009; } \\
\text { Norton \& Herek, 2013; Páez et al., } 2015\end{array}$ \\
\hline & Ethnicity/nationality & Case \& Stewart, 2013; Tee \& Hegarty, 2006 \\
\hline & Social dominance & $\begin{array}{l}\text { Dierckx et al., 2014; Huffaker \& Kwon, 2016; Rojas, 2012; E. A. } \\
\text { Tebbe et al., 2014b; E. N. Tebbe \& Moradi, } 2012\end{array}$ \\
\hline & $\begin{array}{l}\text { Right-wing } \\
\text { authoritarianism/ } \\
\text { political conservatism }\end{array}$ & $\begin{array}{l}\text { Ali et al., 2016; Grigoropoulos \& Kordoutis, 2015; Huffaker } \\
\text { \& Kwon, 2016, 2016; Nagoshi et al., 2008; Norton \& Herek, } \\
\text { 2013, 2013; Rottenbacher de Rojas, 2012; Tee \& Hegarty, 2006; } \\
\text { Warriner et al., 2013; Willoughby et al., 2010 }\end{array}$ \\
\hline & Tolerance to ambiguity & Huffaker \& Kwon, 2016; E. A. Tebbe et al., 2014b \\
\hline & Moral dogmatism & Willoughby et al., 2010 \\
\hline & Self-esteem & Hill \& Willoughby, 2005; Willoughby et al., 2010 \\
\hline & Aggression proneness & Tebbe et al., 2014b; Warriner et al., 2013 \\
\hline \multirow{2}{*}{ 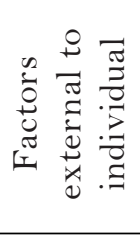 } & $\begin{array}{l}\text { Contact with trans } \\
\text { people }\end{array}$ & $\begin{array}{l}\text { Hill \& Willoughby, 2005; Huffaker \& Kwon, 2016; King et al., } \\
\text { 2009; Norton \& Herek, 2013; Tee \& Hegarty, 2006; Walch, } \\
\text { Sinkkanen, et al., 2012; Willoughby et al., } 2010\end{array}$ \\
\hline & $\begin{array}{l}\text { Information about trans } \\
\text { people }\end{array}$ & $\begin{array}{c}\text { Broockman \& Kalla, 2016; Case \& Stewart, 2013; Huffaker \& } \\
\text { Kwon, 2016; Willoughby et al., } 2010\end{array}$ \\
\hline \multirow{4}{*}{ 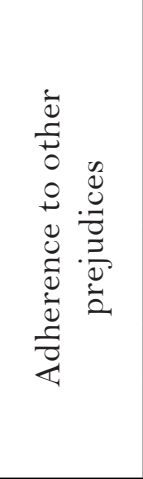 } & $\begin{array}{l}\text { Homophobia/sexual } \\
\text { prejudice }\end{array}$ & $\begin{array}{l}\text { Grigoropoulos \& Kordoutis, 2015; Hill \& Willoughby, 2005; } \\
\text { Nagoshi et al., 2008; Norton \& Herek, 2013; Rottenbacher de } \\
\text { Rojas, 2012; E. A. Tebbe et al., 2014; E. N. Tebbe \& Moradi, } \\
\text { 2012; Tee \& Hegarty, 2006; Willoughby et al., 2010; Worthen, } \\
2016\end{array}$ \\
\hline & Modern/hostile sexism & $\begin{array}{l}\text { Nagoshi et al., 2008; E. A. Tebbe et al., 2014b; Tee \& Hegarty, } \\
\text { 2006; Warriner et al., } 2013\end{array}$ \\
\hline & Beliefs about gender & Norton \& Herek, 2013; Tee \& Hegarty, 2006 \\
\hline & $\begin{array}{l}\text { Beliefs on traditional } \\
\text { gender roles }\end{array}$ & $\begin{array}{l}\text { Hill \& Willoughby, 2005; E. N. Tebbe \& Moradi, 2012; } \\
\text { Willoughby et al., } 2010\end{array}$ \\
\hline
\end{tabular}


In relation to individual characteristics, the studies examine the role of variables such as gender, sexual orientation, religiosity/religious fundamentalism, age, educational level, ethnicity, nationality, social dominance, right-wing authoritarianism, political conservatism, tolerance to ambiguity, moral dogmatism, self-esteem, aggression proneness, and feminist identity. Being 'male' seems to be the main explanatory characteristic. Being heterosexual, being religious, being a religious fundamentalist and being older also rank high as explanations for transphobia and trans prejudice. Ethnicity and nationality are also explored in explaining attitudes towards trans people. For instance, on their study Case and Stewart (2013) found that 'coloured's participants had more negative attitudes than whites, while Tee and Hegarty (2006) found that non-British participants and nonwhite participants showed a greater opposition to the rights of trans people in the United Kingdom. High right-wing authoritarianism, low tolerance of ambiguity and low selfesteem are also put forward as individual characteristics explaining transphobia and trans prejudice.

Some elements external to the individual are also highlighted as explanations. Prominent among these are previous contact with trans people and the level of information about trans experiences. Drawing on Allport and Pettigrew's interpersonal contact theory, many studies focus on previous contact with trans people to explain transphobia. Some studies found that personal contact with trans people reduces negative attitudes towards them. Certain scholars argue that previous contact with trans people increases knowledge about them, leading to the second external factor: information. According to this, a lack of familiarity with trans experiences is at the heart of prejudices, with low familiarity being due to the low visibility of trans people and the lack of interaction with them.

Finally, individual adherence to other types of prejudices is also highlighted as an explanatory element: in particular, the relationship of transphobia or trans prejudice to homophobia and sexual prejudice, to modern and hostile sexism, and to beliefs about gender binarism and traditional gender roles.

\section{Discursive approaches}

Under discursive approaches I included studies that are in some way associated with the construction of meaning, although some do not explicitly use the label 'discursive' and/or may not see themselves as coming under this field of study. These studies are interested in the construction of gender categories by the attribution of meaning to sexed bodies. Most consist of theoretical reflections. Only a small number are empirical and use qualitative methodology. They come from different disciplines, including sociology, gender studies, philosophy, education and psychology. Three categories were identified within these approaches in relation to gender meanings: production, predominance and effects (Table 3). 
Table 3. Categories and subcategories related to the construction of gender meanings

\begin{tabular}{|c|c|c|}
\hline \multicolumn{2}{|c|}{ Category and subcategory } & References \\
\hline \multirow{3}{*}{ 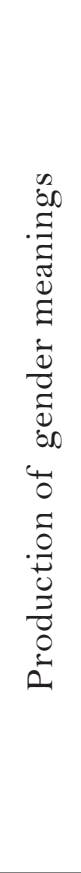 } & Gender as action & $\begin{array}{l}\text { Alessandrin, 2016; Bailey, 2011; Begun \& Kattari, 2016; Bento \& } \\
\text { Pelúcio, 2012; Brower, 2016; Buist \& Stone, 2014; Connell, 2010; } \\
\text { Cruz, 2014; Currah, 2008; Davis, 2014; DePalma \& Jennett, 2010; } \\
\text { Dietert \& Dentice, 2015; Faúndes, 2015; Formby, 2015; Franco } \\
\text { \& Cicillini, 2015; Gilbert, 2009; Lasso Báez, 2014; Lehtonen, } \\
\text { 2016; Loutzenheiser, 2015; McFadden, 2015; Meadow, 2010; } \\
\text { Missé \& Coll-Planas, 2010; Moulin de Souza \& de Pádua Carrieri, } \\
\text { 2015; Myers, 2010; Pacheco \& Pacheco, 2016; Priola, Lasio, De, } \\
\text { \& Serri, 2014; Resende Alves \& Costa Moreira, 2015; Sawyer, } \\
\text { Thoroughgood, \& Webster, 2016; Schilt \& Westbrook, 2009; } \\
\text { Spade, 2015; Suess, } 2014\end{array}$ \\
\hline & Variability & $\begin{array}{l}\text { Bento \& Pelúcio, 2012; Connell, 2010; Franco \& Cicillini, 2015; } \\
\text { Gilbert, 2009; Moulin de Souza \& de Pádua Carrieri, 2015; Schilt, } \\
\text { 2006; Schilt \& Westbrook, 2009; Spade, 2015; Suess, 2014 }\end{array}$ \\
\hline & Language & $\begin{array}{l}\text { Bento \& Pelúcio, 2012; Bettcher, 2007; Buist \& Stone, 2014; } \\
\text { Currah, 2008; DePalma \& Jennett, 2010; Lehtonen, 2016; } \\
\text { Loutzenheiser, 2015; Meadow, 2010; Missé \& Coll-Planas, 2010; } \\
\text { Vincenza Priola et al., 2014; Riggs, 2014 }\end{array}$ \\
\hline \multirow{2}{*}{ 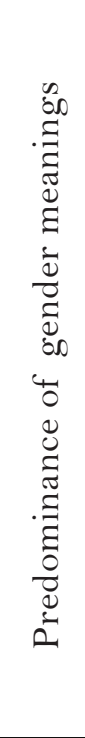 } & Power & $\begin{array}{l}\text { Adrian, 2013; Ansara \& Hegarty, 2012; Bento \& Pelúcio, 2012; } \\
\text { Buist \& Stone, 2014; Currah, 2008; Dean, Victor, \& Grimes, 2016; } \\
\text { DePalma \& Jennett, 2010; Erni, 2013; Gilbert, 2009; Lasso Báez, } \\
\text { 2014; Lehtonen, 2016; Loutzenheiser, 2015; Meadow, 2010; Missé } \\
\text { \& Coll-Planas, 2010; Molina Rodríguez, Guzmán Cervantes, \& } \\
\text { Martínez-Guzmán, 2015; Moulin de Souza \& de Pádua Carrieri, } \\
\text { 2015; Ozeren, Ucar, \& Duygulu, 2016; Priola et al., 2014; } \\
\text { Resende Alves \& Costa Moreira, 2015; Schilt \& Westbrook, 2009; } \\
\text { Spade, 2015; Winter, } 2009\end{array}$ \\
\hline & Social function & $\begin{array}{l}\text { Bettcher, 2007; Faúndes, 2015; Franco \& Cicillini, 2015; Gilbert, } \\
\text { 2009; Loutzenheiser, 2015; Meadow, 2010; Moulin de Souza \& de } \\
\text { Pádua Carrieri, 2015; K. Schilt \& Westbrook, 2009 } \\
\text { Barclay \& Scott, 2006; Collins, McFadden, Rocco, \& Mathis, } \\
\text { 2015; Faúndes, 2015; Myers, 2010; Spade, } 2015 \\
\text { Currah, 2008; Meadow, 2010; Spade, } 2015\end{array}$ \\
\hline \multirow{2}{*}{ 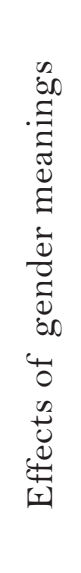 } & Othering & $\begin{array}{l}\text { Adrian, 2013; Ansara \& Hegarty, 2012; Bailey, 2011; Cruz, 2014; } \\
\text { Currah, 2008; Curtis, 2016; Dean et al., 2016; DePalma \& Jennett, } \\
\text { 2010; Franco \& Cicillini, 2015; Gilbert, 2009; Lehtonen, 2016; } \\
\text { Loutzenheiser, 2015; Meadow, 2010; Myers, 2010; Páez et al., } \\
\text { 2015; Rasmussen, Sanjakdar, Allen, Quinlivan, \& Bromdal, 2015; } \\
\text { Winter, 2009 }\end{array}$ \\
\hline & Unintelligibility & $\begin{array}{l}\text { Bailey, 2011; Bettcher, 2007; Buist \& Stone, 2014; Erni, 2013; } \\
\text { Faúndes, 2015; Gilbert, 2009; Lasso Báez, 2014; Meadow, 2010; } \\
\text { Missé \& Coll-Planas, 2010; Molina Rodríguez et al., 2015; } \\
\text { Moulin de Souza \& de Pádua Carrieri, 2015; Nadal, Skolnik, } \\
\text { \& Wong, 2012; Pacheco \& Pacheco, 2016; Priola et al., 2014; } \\
\text { Resende Alves \& Costa Moreira, 2015; Spade, 2015; Suess, 2014 }\end{array}$ \\
\hline
\end{tabular}


The first category addresses the question of how gender categories are produced. Here, gender is considered an action, something that we do. In this sense, many studies draw on Judith Butler's notion of gender performativity. This refers to the idea that gender is not natural, but rather achieved through the repetition of social practices. For instance, gender is done when a legal gender is attributed to someone based on their genitals at birth or when a trans man is told how to 'behave like a guy'. This is not to say that gender is not real, but rather to highlight the idea that it is not a predetermined essence. As Meadow (2010) states, gender is real in its consequences, i.e. meanings about gender actually constitute gender categories and subjectivities.

Variability of gender meanings is a feature highlighted in these approaches. For instance, as some studies emphasise (Bailey, 2011; Schilt, 2006), masculinity has no fixed meaning, but changes over time and places, gender meanings are context-dependent. This is explained by the fact that gender is something that we do through repetition and repetition is unstable. Therefore, gender performativity is always an ideal rather than something that is actually achieved.

The empirical studies carried out using these approaches focus primarily on the role of language in the construction of gender meanings. The main idea is that language not only represents, but also produces reality. Several studies analyse the effects of language in different contexts, such as psychology, court decisions, policy, and the media. For instance, Ansara \& Hegarty (2012) analyse how the language used in many psychological studies construct children with no gender-normative behaviour or characteristics as pathological or disordered. In a similar vein, Meadow's (2010) discursive analysis of court decisions for gender reclassification captures how judges make and solidify gender categories themselves.

The second category attempts to answer the question of predominance: why some meanings prevail over others, thus becoming gender norms. These norms establish that there are only two natural and immutable categories - men and women-, compulsory heterosexuality and the supremacy of masculinity. This question is addressed in the literature by paying attention to both power and the purpose that dominant meanings about gender serve. Many studies draw on the Foucauldian notion of power-knowledge. According to this notion, power defines certain knowledge as truth, while at the same time this knowledge reinforces power, i.e. power delimits what is accepted as truth and what is not. It also delimits what can be said and by whom. The recognised competence of psychiatrists to assess what is 'normal' gender identity and what is not and the capacity of the State to determine someone's legal gender are examples illustrating the notion of power-knowledge.

At the same time, other scholars point to the purposes that dominant meanings about gender serve in the organisation of society. First, the fabrication of dichotomous and permanent gender categories plays a role in upholding heterosexuality, reproduction and the nuclear family, where gender acts as a sign for sexual encounter. Therefore, although gender and sexuality can be analysed separately, analysing the one without the other would not be fruitful. A second purpose of the fabrication of dichotomous and permanent gender categories is the organisation of the economy, based on the gendered division of work. Given the inseparability of gender and sexuality and that heteronormativity is functional to the economic system in terms of production and reproduction, the exclusion of trans people is not only cultural, but also economic. Another purpose is the 
identification of individuals for state security and anti-terrorism reasons. This requires the unalterable correspondence between individuals and identity documents, one reason why official recognition of gender transition revolves around the notions of permanence and irreversibility.

Two effects were identified in relation to prevailing gender meanings (third category). The first one, othering, relates to the process by which 'the other' is constructed as not belonging to the category of 'normal people', those following gender norms. This leads to the reification of differences and the stigmatisation of trans people. This category draws particularly on Ervin Goffman's theory of stigma. For instance, many authors argue that the pathologisation of trans identities by psychiatry and psychology has led to stigma, depicting trans people as mentally ill. They are therefore seen as not human (Buist \& Stone, 2014) or as abnormal, non-natural or monstrous (Franco \& Cicillini, 2015).

The second effect is the question of unintelligibility. Drawing especially on Judith Butler's work, this subcategory focuses on the notion that trans people are inconceivable, unthinkable within existing gender norms. Regardless of how they present themselves, people seek to know their 'true' gender category, ultimately defined by the type of genitals they had at birth. Therefore, trans people are not intelligible as trans but rather reduced to actually men or women who are, as Bettcher (2007) expresses it, either deceiving others about their true gender category or making others believe they are a gender category that they are actually not. Thus the trans subject is not, unlike 'men' and 'women', considered a subject (Suess, 2014). In this regard, discrimination is framed as a 'discursive exclusion' (Suess, 2014).

\section{Discussion}

Two broad theoretical perspectives were identified: cognitive approaches and discursive approaches. Cognitive approaches are one of the main paradigms in the discipline of psychology, whereas discursive approaches are rather interdisciplinary. Both take into account the role that gender norms play in discrimination against trans people. However, the status attributed to these norms varies. In cognitive approaches, gender norms are conceptualised as a belief system that is 'out there' and is internalised by individuals, whereas in discursive approaches norms are conceived as social practices: they are done and reproduced. The first approach situates the problem in the mind of (some) individuals, the second as social and historical practices and processes. The different implications of the two accounts are discussed below.

Cognitive approaches situate the problem of transphobia in the mind of some individuals, whereas others are considered free of transphobia or less affected by it. As a consequence, it individualises the problem of discrimination and it risks homogenising, essentialising and stigmatising certain populations, such as religious and ethnic minorities or poor people. In this sense, it can reinforce the idea that, for example, being a member of a specific religious or ethnic community and accepting trans identities are mutually exclusive, contributing to the creation of a polarisation between the 'egalitarian us' and the 'transphobic them'. 
These approaches also treat attitudes as having a predefined, coherent and stable content that can be identified and measured through questionnaires. However, defining the content 'on an a priori and global basis' can have dangerous counter effects (Wetherell $\&$ Potter, 1992, p. 71). If the content of transphobia is defined as fixed and invariable, we may overlook transphobic claims that are not expressed in the way we expect them to do it (for instance, as open hostility or negative valuing towards trans people).

Moreover, cognitive approaches conceive attitudinal change as the result of a cognitive input in form of contact and information about trans people. Familiarity with trans experiences may indeed play a role in people's ideas about trans people, since it can make visible non-hegemonic meanings about gender. However, this explanation seems problematic in two ways. On the one hand, it assumes that there is an evident truth about trans people that can be both taught and learned, as if there was no battle over meanings. On the other hand, it assumes that people will unquestionably accept new meanings, without reflecting on them and their implications.

Alternatively, the attention paid to the construction of meaning by discursive approaches seems promising to understand discrimination against trans people. These approaches pay attention to the construction of hegemonic meanings, their social functions and their effects on trans people. However, most studies identified under these approaches are theoretical and in their effort to characterise gender norms as social practices they seem to convey a certain notion of social determinism. As a consequence, it would seem that gender norms are a congruent and consistent ensemble that occupies all symbolic space and that people just reproduce them thoughtlessly.

In view of the above, it is argued that a discursive psychological perspective towards transphobic attitudes and ideology may offer important insights to address the limitations described above.

\section{Transphobic attitudes and ideology: The theoretical proposal of discursive psychology}

Discursive psychology (DP) is a theoretical and analytical approach to discourse which treats talk and text as an object of study in itself, and psychological concepts as socially managed and consequential in interaction' (Wiggins, 2017). It emerged within psychology in the UK in the 1980s (Martínez-Guzmán, Stecher, \& Íñiguez-Rueda, 2016; Wiggins, 2017) and has remarkably expanded the boundaries of the discipline. Its main contribution has been to move the study of psychological matters into the areas of language and social interaction (Sisto Campos, 2012; Weatherall, 2012).

DP does not reject the idea that cognitive processes exist, but it argues that these should not be the main object of study, setting an important difference with cognitive approaches in psychology. Within this paradigm, attitudes towards trans people are not considered a mental reality but a social practice. The expression of the attitude is thus 'the reality that needs to be studied' (Billig, 1991, p. 15). The study of transphobic attitudes from a DP perspective entails some conceptual differences with mainstream cognitive approaches. 
First, the separation between the attitude (evaluation or judgement) and the object of the attitude becomes virtually impossible to sustain (Potter \& Wetherell, 1987), the object - in this case, trans people - is discursively constructed in the course of doing evaluation. The use of the same term (e.g. 'trans people') to refer to the object of the attitude does not mean that it is understood in the same way by different people. It is therefore important to examine not only the judgement expressed about trans people, but also the construction of the social category 'trans people' itself.

Second, attitudes are thought to be both personal and social (Billig, 1991). The DP approach to attitudes assumes that knowledge is socially shared and that common sense contains conflicting themes (Billig et al., 1988). In fact, the notions of dilemma and ideological dilemma are central in this approach: common sense provides people with the 'seeds for contrary themes' which can conflict in dilemmatic situations (1988, p. 20). Within this perspective, attitudes are thus defined as 'stances taken in matters of controversy: they are positions in arguments' (Billig, 1991, p. 143). Therefore, they are not assumed to be a coherent, permanent and unitary mental reality, but rather a fragmented, contradictory and changeable practice that evolve with the argumentative context. In this sense, transphobia is possible when cracks appear in hegemonic gender meanings, leading to a dispute between hegemonic meanings and alternative ones.

Third, within this perspective people are not assumed to only bear and follow rules, but also to create, to interpret and to challenge them. People have an active role in the selection of arguments when they express their attitudes. This brought Wetherell \& Potter (1992) to develop the notion of interpretative repertoires to denote the available resources upon which arguments are built.

Finally, the expression of attitudes is not only argumentative and rhetorical, but also ideological because it has functions that are related to patterns of domination and power (Billig, 1991). In this sense, discourse is 'a set of linguistic practices that maintain and promote certain social relations' (Íñiguez-Rueda \& Antaki, 1994, p. 63). However, the connection between attitudes and ideology should not be examined only in relation to the content of attitudes, but also, and specially, in relation to their effects. For example, a discourse can be racist without mentioning race whatsoever (Wetherell \& Potter, 1992). In fact, sometimes the difference between open and subtle prejudices is not a different in kind, but rather an ability to provide justifications for views (Billig, 1991).

Gender is governed by certain norms that construct the binary opposition between the categories 'woman' and 'man', including the social functions attributed to each category. These norms are particularly visible when they are breached. Indeed, terms such as 'transsexual' and 'transvestite' were coined to give a name to the breaching of those norms (Tosh, 2016). However, the norm was not given a name ${ }^{4}$, which can be understood in terms of 'uninteresting reflexivity': we do not describe or explain what is taken for granted. Discursive practices thus perform norms constituting the binary opposition between women and men but they also re-establish it (or challenge it) when it is breached so that the binary opposition is maintained (or challenged). Discursive practices have the effect of both performing the norm and re-establishing it.

The problem of exclusion and discrimination against trans* people can thus be situated in the norms defining the binary opposition between women and men in specific contexts. People who breach those norms are defined as 'abnormal'. In this sense, in spite of the fact that pathologisation is increasingly questioned, trans people are still overall 
defined as 'not normal'. The theoretical and methodological framework proposed by DP allows understanding how trans people are discursively constructed as such. Instead of taking for granted the definition of 'trans people' or fixing beforehand an academic definition to assess people's attitudes towards them, DP examines how people themselves define, describe, explain and argue about social categories. This prevents researchers and practitioners from reifying the norms that constitute the binary opposition between women and men. From this perspective, the task of researchers and practitioners is not to define themselves gender norms, but rather to determine how people produce them through discursive practices.

Discursive practices not only define social categories but they also legitimise, minimise, justify or promote exclusion and discrimination against them. Conversely, they can also criticise or challenge exclusion and discrimination, thereby promoting other types of social organisation. Because of its focus on discursive practices, this theoretical approach allows us to see how the gendered organisation of society takes place in everyday social interaction and how this organisation is resisted. It enables us to see how norms establishing social categories and their corresponding roles are constantly produced and re-negotiated at the micro-level.

Finally, DP allows for the identification of more 'sophisticated' expressions of views on gender categories that, officially adhering to common values such as equality and inclusion, actually have exclusionary effects and promote unequal social relations. This, in turn, avoids pointing at certain groups of people as more transphobic or sexist than others, thereby avoiding stigmatisation. Therefore, this theoretical framework allows us to understand how the redefined transgression of gender norms nowadays actually keeps on maintaining the binary opposition that sustains the (gendered) organisation of society.

\section{Conclusions}

Cognitive approaches and discursive approaches are two broad theoretical perspectives used in contemporary literature to explain transphobia and discrimination against trans people. However, a number of limitations were identified. These are related to the individualisation of the problem described as a cognitive matter in the first approach and a certain notion of social determinism in the second. It is argued that a distinction between gendered practices on the one hand and transphobic attitudes and ideology on the other may be useful to understand transphobia and discrimination. A discursive psychology approach to attitudes and ideology is suggested to overcome the individualsocial cleavage. 


\section{Notes}

1 The notion of transphobia has been criticised because of its connections with irrational fear, what would potentially lead to the idea that it is an illness (see King et al., 2009; Leal, 2018). However, it is employed in this paper because of (a) its common use both in the scientific literature and outside academia and (b) its strong rhetorical effects (Riggs, 2014). In this paper, I use 'transphobia' to refer to the practices whose effects are the exclusion or discrimination of trans people.

2 The keywords used to identify the documents (exclusion, discrimination, stereotypes, prejudices, transphobia) belong to rather mainstream social research perspectives on discrimination, since research terminology is often theoretically connotated. This may explain the relatively small number of identified publications belonging to the Trans Studies field, whose focus is rather the production of normativity than discrimination itself (Stryker, 2006). Yet, the identification of mainstream research perspectives on transphobia and discrimination against trans people allow us to critically examine them and to establish a (hopefully) fruitful dialogue with them.

$3 \quad$ Term employed by the researchers themselves.

4. Trans and queer activists gave it a name-cisgender-many decades later as a political claim.

\section{References}

Ansara, Y. G. \& Hegarty, P. (2012). Cisgenderism in psychology: Pathologising and misgendering children from 1999 to 2008. Psychology and Sexuality, 3(2), 137-160.

Bailey, M. (2011). Gender/Racial Realness: Theorizing the Gender System in Ballroom Culture. Feminist Studies, 37(2), 365-386.

Barclay, J. M. \& Scott, L. J. (2006). Transsexuals and workplace diversity: A case of "change" management. Personnel Review, 35(4), 487-502.

Begun, S. \& Kattari, S. K. (2016). Conforming for survival: Associations between transgender visual conformity/passing and homelessness experiences. Journal of Gay and Lesbian Social Services, 28(1), 54-66.

Bento, B. \& Pelúcio, L. (2012). Despatologização do gênero: a politização das identidades abjetas. Revista Estudos Feministas, 20(2), 569-581.

Bettcher, T. M. (2007). Evil Deceivers and Make-Believers: On Transphobic Violence and the Politics of Illusion. Hypatia, 22(3), 43-65.

Broockman, D. \& Kalla, J. (2016). Durably reducing transphobia: A field experiment on doorto-door canvassing. Science, 352(6282), 220-224. 
Brower, T. (2016). Visibility and the workplace experiences of trans persons in the United States. In Sexual Orientation and Transgender Issues in Organizations: Global Perspectives on LGBT Workforce Diversity (pp. 149-166). Recuperado de https://www.researchgate.net/publication/301623948_Visibility_and_the_Workplace_Experiences_of_Trans_Persons_in_the United States

Buist, C. L. \& Stone, C. (2014). Transgender Victims and Offenders: Failures of the United States Criminal Justice System and the Necessity of Queer Criminology. Critical Criminology, 22(1), 35-47.

Case, K. A. \& Stewart, B. (2013). Intervention Effectiveness in Reducing Prejudice Against Transsexuals. Journal of LGBT Youth, 10(1/2), 140-158.

Collins, J. C., McFadden, C., Rocco, T. S., \& Mathis, M. K. (2015). The Problem of Transgender Marginalization and Exclusion: Critical Actions for Human Resource Development. Human Resource Development Review, 14(2), 205-226.

Connell, C. (2010). Doing, Undoing, or Redoing Gender? Learning from the Workplace Experiences of Transpeople. Gender \& Society, 24(1), 31-55.

Cruz, T. M. (2014). Assessing access to care for transgender and gender nonconforming people: A consideration of diversity in combating discrimination. Social Science and Medicine, $110,65-73$.

Currah, P. (2008). Expecting Bodies: The Pregnant Man and Transgender Exclusion from the Employment Non-Discrimination Act. Women's Studies Quarterly, 36(3/4), 330-336.

Curtis, A. J. (2016). Conformity or nonconformity? Designing legal remedies to protect transgender students from discrimination. Harvard Journal on Legislation, 53(2), 460-497.

Davis, H. F. (2014). Sex-classification policies as transgender discrimination: An intersectional critique. Perspectives on Politics, 12(1), 45-60.

Dean, M. A., Victor, E., \& Grimes, L. G. (2016). Inhospitable Healthcare Spaces: Why Diversity Training on LGBTQIA Issues Is Not Enough. Journal of Bioethical Inquiry, 13(4), 557-570.

DePalma, R. \& Jennett, M. (2010). Homophobia, transphobia and culture: Deconstructing heteronormativity in English primary schools. Intercultural Education, 21(1), 15-26.

Dierckx, M., Motmans, J., \& Meier, P. (2014). Beyond the box. Mesure d'attitudes en matière de sexisme, d'homophobie et de transphobie. Bruxelles: Institut pour l'égalité des femmes et des hommes.

Dietert, M. \& Dentice, D. (2015). The Transgender Military Experience: Their Battle for Workplace Rights. Journal of Workplace Rights, 5(2), 1-12.

Ermi, J. N. (2013). Legitimating Transphobia: The legal disavowal of transgender rights in prison. Cultural Studies, 27(1), 136-159.

European Union Agency for Fundamental Rights. (2014). Being Trans in the European Union. Comparative analysis of EU LGBT survey data. Luxembourg.

Faúndes, J. M. M. (2015). Géneros, Transgéneros: Hacia Una Noción Bidimensional De La Injusticia. Andamios. Revista de Investigación Social, 12(27), 257-278.

Formby, E. (2015). Limitations of focussing on homophobic, biphobic and transphobic 'bullying' to understand and address LGBT young people's experiences within and beyond school. Sex Education, 15(6), 626-640.

Franco, N. \& Cicillini, G. A. (2015). Brazilian trans teachers in their schooling process. Revista Estudos Feministas, 23(2), 325-346.

Gazzola, S. B. \& Morrison, M. A. (2014). Cultural and Personally Endorsed Stereotypes of Transgender Men and Transgender Women: Notable Correspondence or Disjunction? International Journal of Transgenderism, 15(2), 76-99. 
Gerhardstein, K. R. \& Anderson, V. N. (2010). There's more than meets the eye: Facial appearance and evaluations of transsexual people. Sex Roles, 62(5/6), 361-373.

Gillbert, M. A. (2009). Defeating Bigenderism: Changing Gender Assumptions in the TwentyFirst Century. Hypatia, 24(3), 93-112.

Grigoropoulos, I. \& Kordoutis, P. (2015). Social Factors Affecting Antitransgender Sentiment in a Sample of Greek Undergraduate Students. International Journal of Sexual Health, $27(3), 276-285$.

Hill, D. B. \& Willoughby, B. L. B. (2005). The development and validation of the genderism and transphobia scale. Sex Roles, 53(7/8), 531-544.

Huffaker, L. \& Kwon, P. (2016). A comprehensive approach to sexual and transgender prejudice. Journal of Gay and Lesbian Social Services, 28(3), 195-213.

King, M. E., Winter, S., \& Webster, B. (2009). Contact reduces transprejudice: A study on attitudes towards transgenderism and transgender civil rights in Hong Kong. International Journal of Sexual Health, 21(1), 17-34.

Lasso Báez, R. A. (2014). Transexualidad y servicios de salud utilizados para transitar por los sexos-géneros. CES Psicología, 7(2), 108-125.

Leal, D. (2018). Performatividade transgênera: Equações poéticas de reconhecimento recíproco na recepção teatral. São Paulo: Universidade de São Paulo.

Lehtonen, J. (2016). Experiências de Jovens Não Heterossexuais e Trans na Escolha de Carreira e no Local de Trabalho . In T. Köllen (Ed.), Sexual Orientation and Transgender Issues in Organizations: Global Perspectives on LGBT Workforce Diversity (pp. 289-306). Cham, Switzerland: Springer.

Loutzenheiser, L. W. (2015). 'Who are you calling a problem?' Addressing transphobia and homophobia through school policy. Critical Studies in Education, 56(1), 99-115.

McFadden, C. (2015). Lesbian, Gay, Bisexual, and Transgender Careers and Human Resource Development: A Systematic Literature Review. Human Resource Development Review, 14(2), 125-162.

Meadlow, T. (2010). "A Rose is a Rose" On Producing Legal Gender Classifications. Gender \& Society, 24(6), 814-837.

Missé, M. \& Coll-Planas, G. (2010). El género desordenado. Críticas entorno a la patologización de la transexualidad. Barcelona; Madrid: Editorial Egales.

Molina Rodríguez, N. E., Guzmán Cervantes, O. O., \& Martínez-Guzmán, A. (2015). Identidades transgénero y transfobia en el contexto mexicano: Una aproximación narrativa. Quaderns de Psicologia, 17(3), 71-82.

Moulin Souza, E. \& de Pádua Carrieri, A. (2015). When Invisibility Is Impossible: Body, Subjectivity, and Labor Among Travestis and Transsexuals. Journal of Workplace Rights, 5 (2), $1-11$.

Myers, P. R. (2010). Jane Doe v. Boeing Company: Transsexuality and Compulsory Gendering in Corporate Capitalism. Feminist Studies, 36(3), 493-517.

Nadal, K. L., Skolnilk, A., \& Wong, Y. (2012). Interpersonal and systemic microaggressions toward transgender people: Implications for counseling. Journal of LGBT Issues in Counseling, $6(1), 55-82$.

Nagoshi, J. L., Adams, K. A., Terrell, H. K., Hill, E. D., Brzuzy, S., \& Nagoshi, C. T. (2008). Gender differences in correlates of homophobia and transphobia. Sex Roles, 59(7/8), 521-531.

National Geographic. (2016, December). Special Issue - Gender Revolution. Retrieved from http://www.nationalgeographic.com/magazine/2017/01/

Norton, A. T. \& Herek, G. M. (2013). Heterosexuals' Attitudes Toward Transgender People: Findings from a National Probability Sample of U.S. Adults. Sex Roles, 68(11/12), 738-753. 
Ozeren, E., Ucar, Z., \& Duygulu, E. (2016). Silence speaks in the workplace: Uncovering the experiences of LGBT employees in Turkey. In Sexual Orientation and Transgender Issues in Organizations: Global Perspectives on LGBT Workforce Diversity (pp. 217-232). Cham, Switzerland: Springer

Pacheco, R. A. S. \& Pacheco, I. S. (2016). Direito, violências e sexualidades: a transexualidade em um contexto de direitos. Revista Estudios Socio-Jurídicos, 18(2), 201-226.

Páez, J., Hevia, G., Pesci, F., \& Rabbia, H. H. (2015). Construcción y validación de una escala de actitudes negativas hacia personas trans. Revista de Psicología, 33(1), 151-188.

Priola, V., Lasio, D., De, S., \& Serri, F. (2014). The Sound of Silence. Lesbian, Gay, Bisexual and Transgender Discrimination in "Inclusive Organizations." British Journal of Management, $25(3), 488-502$.

Rasmussen, M. L., Sanjakdar, F., Allen, L., Quinlivan, K., \& Bromdal, A. (2015). Homophobia, transphobia, young people and the question of responsibility. Discourse: Studies in the Cultural Politics of Education, 38(1), 30-42.

Resende Alves, C. E., \& Costa Moreira, M. I. (2015). Do uso do nome social ao uso do banheiro: (trans)subjetividades em escolas brasileiras. Quaderns de Psicologia, 17(3), 59-69.

Riggs, D. W. (2014). What makes a man? Thomas Beatie, embodiment, and "mundane transphobia." Feminism and Psychology, 24(2), 157-171.

Rottenbacher Rojas, J. M. (2012). Conservadurismo político, homofobia y prejuicio hacia grupos transgénero en una muestra de estudiantes y egresados universitarios de Lima. Pensamiento Psicológico, 10(1), 23-37.

Sawyer, K., Thoroughgood, C., \& Webster, J. (2016). Queering the gender binary: Understanding transgender workplace experiences. In Sexual Orientation and Transgender Issues in Organizations: Global Perspectives on LGBT Workforce Diversity (pp. 21-42). Cham, Switzerland: Springer

Schilt, K. (2006). Just One of the Guys? How Transmen Make Gender Visible at Work. Gender \& Society, 20(4), 465-490.

Schilt, K. \& Westbrook, L. (2009). Doing Gender, Doing Heteronormativity: "Gender Normals," Transgender People, and the Social Maintenance of Heterosexuality. Gender and Society, 23(4), 440-464.

Spade, D. (2015). Normal Life: Administrative Violence, Critical Trans Politics and the Limits of Law. USA: Duke University Press. Recuperado de https://books.google.com.br/books/about/ Normal_Life.html?id=dIiLRQAACAAJ\&redir_esc $=\mathrm{y}$

Stryker, S. (2006). (De)Subjugated Knowledges: An Introduction to Transgender Studies. In $S$. Stryker \& S. Whittle (Eds.), The Transgender Studies Reader (pp. 1-18), New York: Routledge. Suess, A. (2014). Cuestionamiento de dinámicas de patologización y exclusión discursiva desde perspectivas trans e intersex. Revista de Estudios Sociales, 49, 128-143.

Tebbe, E. A., Moradi, B., \& Ege, E. (2014). Revised and abbreviated forms of the genderism and transphobia scale: Tools for assessing anti-trans* prejudice. Journal of Counseling Psychology, 61(4), 581-592.

Telbbe, E. N. \& Moradi, B. (2012). Anti-transgender prejudice: a structural equation model of associated constructs. Journal of Counseling Psychology, 59(2), 251-261.

Tee, N. \& Hegarty, P. (2006). Predicting opposition to the civil rights of trans persons in the United Kingdom. Journal of Community and Applied Social Psychology, 16(1), 70-80.

Transgender Europe [TGEU]. (2016). Transrespect versus Transphobia research project. Recuperado de https://assets-dossies-ipg-v2.nyc3.digitaloceanspaces.com/sites/3/2018/04/ TGEU_O-circulo-vicioso-da-violencia_2017.pdf 
Walch, S. E., Ngamake, S. T., Francisco, J., Stitt, R. L., \& Shingler, K. A. (2012). The attitudes toward transgendered individuals scale: Psychometric properties. Archives of Sexual Behavior, 41(5), 1283-1291.

Walch, S. E., Sinkkanen, K. A., Swain, E. M., Francisco, J., Breaux, C. A., \& Sjoberg, M. D. (2012). Using Intergroup Contact Theory to Reduce Stigma Against Transgender Individuals: Impact of a Transgender Speaker Panel Presentation. Journal of Applied Social Psychology, 42(10), 2583-2605.

Warriner, K., Nagoshi, C. T., \& Nagoshi, J. L. (2013). Correlates of Homophobia, Transphobia, and Internalized Homophobia in Gay or Lesbian and Heterosexual Samples. Journal of Homosexuality, 60(9), 1297-1314.

Willoughby, B. L. B., Hill, D. B., Gonzalez, C. A., Lacorazza, A., Macapagal, R. A., Barton, M. E., \& Doty, N. D. (2010). Who hates Gender outlaws? A multisite and multinational evaluation of the Genderism and Transphobia Scale. International Journal of Transgenderism, 12(4), 254-271.

Winter, S. (2009). Lost in transition: Transpeople, transprejudice and pathology in Asia. International Journal of Human Rights, 13(2/3), 365-390.

Worthen, M. G. F. (2016). Hetero-cis-normativity and the gendering of transphobia. International Journal of Transgenderism, 17(1), 31-57.

\section{SARA AGUIRRE-SÁNCHEZ-BEATO}

https://orcid.org/0000-0003-2261-8633x

$\mathrm{PhD}$, Postdoctorate researcher and gender and diversity expert at the

Université libre de Bruxelles (ULB), Belgium

Adresse: Avenue Franklin Roosevelt 50, 1050 Bruxelles, Belgium

E-mail: saguirre@ulb.ac.be

\begin{tabular}{|l|l|}
\hline \multirow{3}{*}{ Historic } & Submission: 01/17/2019 \\
& Review: 05/03/2020 \\
& Accept: 08/07/2020 \\
\hline
\end{tabular}

